PUSTABIBLIA: Journal of Library and Information Science

ISSN 2549-3493 (Print); ISSN 2549-3868 (Online)

DOI: http://dx.doi.org/10.18326/pustabiblia.v4i2.179-208

SK Dirjen Risbang-Kemristekdikti No 23/E/KPT/2019 (Peringkat 4 SINTA)

\title{
Disrupsi Kamera Digital terhadap Pencatatan Informasi Pemustaka di UPT Perpustakaan ISI Surakarta
}

\author{
Joko Setiyono \\ UPT Perpustakaan, Institut Seni Indonesia (ISI) Surakarta \\ jjokko@gmail.com \\ Diajukan: 31-05-2020; Direview: 23-07-2020; Diterima: 02-08-2020; Direvisi:
}

09-11-2020

\begin{abstract}
Digital cameras have become a technological device that is increasingly being owned in private. Especially for the millennial generation, as well as the library users who are served by the ISI Surakarta Library. For those born in the early 2000s or the so-called millennial generation, digital cameras are important devices to facilitate their daily activities. This disruption was mainly triggered by the digital camera innovation integrated in cellular telephones. This trend becomes interesting for further investigation, with the aim of research to determine the use of digital cameras by users at the UPT Library of ISI Surakarta. Using a descriptive research method, the research population was the library users of the ISI Surakarta Library, with a research sample of 144 respondents. Data collection was carried out by observation and using a research instrument in the form of a questionnaire. The results showed the grand mean of 3,734 which is on the scale range from 3.40 to 4.20 which means it has a high level. The reliability of the instrument in the form of an alpha coefficient was 0.981> $0.60 \mathrm{r}$ table which was significant. The conclusion of this research is 1) Ownership of digital cameras in the majority of users is to have a smartphone/cellphone camera only. 2) Public users use digital cameras to capture supporting details (author, title, publisher, year of publication, book cover, keywords, table of contents, bibliography, abbreviations or symbols) as a way of recording them. 3) The disruption of digital cameras to information recording by the main users for the reason that recording information with a digital camera is faster.
\end{abstract}




\begin{abstract}
Abstrak
Kamera digital telah menjadi perangkat teknologi yang semakin banyak dimiliki secara pribadi. Terlebih bagi para generasi milenial, sebagaimana para pemustaka yang dilayani oleh UPT Perpustakaan ISI Surakarta. Bagi mereka yang lahir pada awal tahun 2000 atau yang disebut generasi milenial, kamera digital menjadi gawai penting untuk memfasilitasi aktivitas keseharian. Disrupsi ini terutama dipicu inovasi kamera digital yang terintegrasi dalam telepon seluler. Kecenderungan ini menjadi menarik ditelisik lebih jauh, dengan penelitian yang bertujuan untuk mengetahui pemanfaatan kamera digital oleh pemustaka di UPT Perpustakaan ISI Surakarta. Menggunakan metode penelitian deskriptif, adapun populasi penelitian adalah pemustaka UPT Perpustakaan ISI Surakarta, dengan sampel penelitian sebanyak 144 responden. Pengumpulan data dilakukan dengan observasi dan menggunakan instrumen penelitian berupa angket. Hasil penelitian menunjukan grand mean sebesar 3,734 yang berada pada rentang skala 3,40 - 4,20 yang berarti memiliki tingkat yang tinggi. Reliabilitas instrumen berupa koefisien alpha bernilai 0,981 >0,60 $\mathrm{r}$ tabel yang bermakna reliabel. Kesimpulan penelitian adalah 1) Kepemilikan kamera digital pada pemustaka mayoritas adalah memiliki kamera smartphone/handphone saja. 2) Pemanfaatan kamera digital oleh pemustaka umumnya untuk memotret informasi supporting details (pengarang, judul, penerbit, tahun terbit, cover buku, kata kunci, daftar isi, daftar pustaka, singkatan atau simbol) sebagai cara mencatatnya. 3) Disrupsi kamera digital terhadap pencatatan informasi oleh pemustaka utamanya karena alasan mencatat informasi dengan kamera digital menjadi lebih cepat (faster).
\end{abstract}

Keywords: $\quad$ Kamera digital, Pemustaka, Kepemilikan, Pemanfaatan, Disruption

\title{
1. PENDAHULUAN
}

Sebagai ekstensi indra penglihatan, kamera digital berkembang semakin canggih dan terjangkau. Serta semakin mudah, semakin sederhana, dan kian bersahabat dalam pemakaiannya. Kelebihan lain, kamera digital bisa ditanamkan ke berbagai benda dan peralatan. Ada drone yang dapat disuruh menjelajah tempat-tempat yang diinginkan. Ada closed circuit television (CCTV) sebagai pengawas yang siap siaga nonstop. Beragam kamera tersembunyi yang bisa menyaru wujud apa saja.

Yang paling akrab bagi manusia masa kini adalah telepon seluler berkamera. Orang nyaris tak pernah lepas dari telepon seluler, menyanding kamera digital ke mana pun. Orang dalam bepergian menjadikan telepon seluler sebagai tentengan wajib yang tak bisa tertinggalkan. Membuat orang 
leluasa untuk jepret sana jepret sini mengabadikan setiap peristiwa yang ditemuinya. Orang semakin rajin memotret apa saja, muncullah kegemaran baru yaitu selfie (swafoto) serta nge-vlog. Beragam kreativitas dituangkan, foto-foto dan video-video dihasilkan setiap hari, setiap jam, setiap menitnya. Tidak terbayangkan berapa volume yang terakumulasi. Berlimpah kekayaan pengetahuan yang kemudian dapat diabadikan berkat kamera digital ini.

Kamera digital yang mulai dikenalkan pada era 1980-an kini menjadi telah peralatan pribadi. Ia memperluas jangkauan indera penglihatan/ mata, memperkuat daya jelajah mata. Orang menjadi leluasa untuk setiap saat memotret atau merekam objek yang dianggap penting, menarik, atau unik. Memotret dan merekam meningkat frekuensinya, hampir setiap hari dikerjakan. Karena memotret dan merekam kini menjadi lebih mudah dan murah untuk dilakukan. Sehingga aktivitas ini menghasilkan ber-bytebyte catatan pengetahuan. Catatan pengetahuan berformat digital yang digandrungi oleh generasi milenial.

Tak heran bila lembaran-lembaran kertas semakin sepi dari huruf dan angka. Fenomena tersebut diperberat oleh adanya situs-situs berbagi video online serta beragam media sosial. Terjadi demokratisasi yang luar biasa dari segi publisher.

Sebab seorang individu pun bisa menjadi publisher untuk membagi pengetahuannya dengan memanfaatkan situs-situs tersebut. Menjadi youtuber, vlogger adalah pilihan hobi yang kian populer. Maka situs Youtube dibanjiri oleh banyak sekali video yang memiliki beragam jenis konten. Dari konten dokumentatif, kreatif imajinasi, edukatif, sampai rekreatif, dari konten kuliner sampai kosmetik, dari dunia flora fauna sampai dunia panggung gemerlap selebrita, dari kehidupan liar hutan belantara sampai kehidupan privat, dari sketsa komedi sampai rekaman tragedi bencana alam, dsb. Semua tersimpan dan tercatat siapa publisher dan para penontonnya di ruang global situs berbagi video Youtube. YouTube tidaklah sendirian ada situs berbagi video lainnya ada Blib, Metacafe, Veoh, Dailymotion, Yahoo! Screen, Hulu, dan sebagainya. 
Format penyimpanan digital ini turut andil dalam semakin maraknya pemanfaatan kamera digital. Belanja kuota internet, belanja kartu memori mengeser belanja kertas, buku tulis dan pena dari daftar belanja. Buku-buku tulis nyaris tak tersentuh lagi. Pena mulai jarang dijamah. Pena versus kamera mewakili deskripsi padat dari fenomena tersebut. Kamera digital seolah sedang bertarung sengit dengan pena, pensil, balpoint, dan aneka peralatan menulis lainnya. Kedua jenis peralatan yang berbeda tersebut berlomba menawarkan solusi untuk mengabadikan informasi dan pengetahuan. Orang mulai malas membuat deskripsi tertulis dan mulai suka memotret atau merekamnya sebagai sebuah dokumen.

Dari awalnya coba-coba mengenal catatan digital, lalu mulai mencoba membuat, sampai akhirnya terbiasa dengan catatan digital. Beragam aplikasi ditawarkan untuk dapat diunduh dan dimanfaatkan oleh masyarakat. Seperti aplikasi catatan digital Evernote, LectureNotes, Google Drive, Gnotes, ColorNote, dsb. Hal ini tidak terlepas berkat adanya inovasi berupa integrasi kamera digital ke dalam ponsel.

Fenomena ini sungguh menarik untuk dikaji lebih mendalam dengan mempertajam fokus penelitian pada segmen tertentu dari elemen sosial. Keputusan akhirnya memilih elemen sosial pemustaka dari sebuah perpustakaan perguruan tinggi seni. Pertimbangan mereka ini dekat dengan aktivitas pekerjaan penulis, yaitu sebagai pustakawan perguruan tinggi. Terlebih pemustaka di mana penulis beraktivitas adalah kelompok sosial yang kuat untuk dapat dikategorikan sebagai generasi milenial. Yaitu pemustaka dari perpustakaan sebuah lembaga pendidikan tinggi yang mulai padat aktivitasnya dalam mencari informasi ilmiah. Kelompok sosial yang disebut sebagai mahasiswa.

Menurut hemat penulis, mengkaji bagaimana kamera digital bila berada di tangan pemustaka adalah aktivitas penelitian yang tidak dapat dilewatkan begitu saja. Urgensi penelitian ini menjadi penting mengingat perpustakaan umumnya memiliki tata-tertib yang melarang untuk memotret di ruang perpustakaan. Mendapatkan gambaran atau potret empiris bagaimana mereka para pemustaka yang tergolong generasi milenial ini 
memanfaatkan kamera digital dalam aktivitas studi mereka; khususnya terkait aktivitas di perpustakaan akan menjadi referensi untuk membuat regulasi perpustakaan yang baik. Kita maklumi bahwa aktivitas yang paling menonjol adalah aktivitas penelusuran dan pencatatan informasi dari khazanah koleksi bahan pustaka. Mencari-cari judul buku yang mereka butuhkan, membacanya dan kemudian membuat catatan hal-hal penting yang perlu mereka ingat atau simpan.

Di tengah padatnya aktivitas pemustaka yang berstatus sebagai mahasiswa kunjungan mereka ke perpustakaan tentu harus dimanfaatkan dengan sebaik mungkin dan seefektif mungkin. Agar supaya berbagai macam aktivitas studi dan aktivitas pengembangan diri serta aktivitas sosial lainnya dapat berjalan tanpa berbenturan satu dengan yang lainnya. Optimalisasi segala macam sarana dan prasarana pendukung aktivitas manusia perlu ditempuh. Seperti halnya dengan sarana berupa produk-produk teknologi terbaru. Berbagai macam gawai elektronik serta digital siap mempermudah berbagai aktivitas studi dan ekspresi/aktualisasi diri. Tak pelak lagi hadirnya kamera digital yang terintegrasi atau tertanam dalam perangkat ponsel dengan menyandang julukan smartphone ini lantas mendapat penerimaan yang begitu besar dari para pemustaka generasi milenial ini. Generasi yang oleh para ahli dan peneliti biasa diidentifikasikan lahir pada awal 1980-an sampai pertengahan tahun 1990-an hingga awal 2000-an. Segmen sosial yang menjadi objek pengamatan sebagai sumber informasi utama yang memperkaya dan membangun sajian terhadap wacana dalam buku ini.

Fokus yang menjadi bidikan dalam menangkap fenomena latar belakang tersebut di atas dan kemudian menuangkannya dalam kajian ini adalah pernyataan tentang pemanfaatan kamera digital oleh pemustaka. Dalam wacana ini pemustaka dimaksud adalah pemustaka dari perpustakaan perguruan tinggi. Lebih spesifiknya adalah pemustaka dari UPT Perpustakaan Institut Seni Indonesia (ISI) Surakarta. Asumsi awal yang memicu yaitu bahwa pemanfaatan kamera digital oleh pemustaka telah mendisrupsi terhadap cara mencatat informasi bagi pemustaka. 
Selanjutnya lebih detail lagi pernyataan ini diturunkan menjadi tiga buah pertanyaan yang menjadi rumus untuk membingkai permasalahan yang menjadi fokus kajian. Pertama, tentang bagaimana kepemilikan kamera digital pemustaka. Yang akan mensigi tentang macam atau jenis kepemilikan kamera digital, jumlah kepemilikan kamera digital, serta mengenai waktu mulai memiliki kamera. Kedua, tentang bagaimana pemanfaatan kamera digital oleh pemustaka. Menggali lebih dalam apakah kamera digital digunakan untuk: Memotret informasi summaries (ringkasan, abstrak, kesimpulan, penutup) sebagai cara mencatatnya. Memotret informasi supporting details (pengarang, judul, penerbit, tahun terbit, cover buku, kata kunci, daftar isi, daftar pustaka, singkatan atau simbol) sebagai cara mencatatnya. Memotret informasi summaries (ringkasan, abstrak, kesimpulan, penutup) sebagai cara mencatatnya. Hal ini adalah berkaitan dengan bahan pustaka yaitu buku. Bahan pustaka utama yang menjadi sumber rujukan informasi bagi pemustaka.

Ketiga, tentang bagaimanakah disrupsi kamera digital terhadap pencatatan informasi pemustaka. Apakah mereka memilihnya dengan pertimbangan : Mencatat informasi dengan kamera digital menjadi lebih mudah (simpler). Mencatat informasi dengan kamera digital menjadi lebih murah (cheaper). Mencatat informasi dengan kamera digital menjadi lebih terjangkau (accessible). Mencatat informasi dengan kamera digital menjadi lebih cepat (faster). Merujuk kepada Rhenald Kasali (2017) berkaitan dengan tema disrupsi.

\section{TINJAUAN PUSTAKA}

\section{A. Kamera Digital}

Kamera digital pertama kali dikembangkan oleh Fuji pada tahun 1988, yang menggunakan kartu memori $16 \mathrm{MB}$ untuk menyimpan data foto yang diambil (foldertekno.com). Sementara itu dalam laman wikipedia menyebutkan kamera digital adalah alat untuk membuat gambar dari objek untuk selanjutnya dibiaskan melalui lensa pada sensor Charge-Coupled Device (CCD), sensor Complimentary Metal-Oxide Semiconductor (CMOS) dan 
akhir-akhir ini pada sensor BSI-CMOS (Back Side Illuminated) sensor yang lebih irit daya untuk kamera yang lebih canggih yang hasilnya kemudian direkam dalam format digital ke dalam media simpan digital (id.wikipedia. org). Dengan teknologi digital, untuk merekam atau memotret gambar suatu obyek kamera digital tidak lagi memerlukan atau menggunakan film. Kamera digital memproses rekaman intensitas cahaya yang masuk melalui lensa dengan sensor perekam dengan modus mengubah cahaya menjadi sinyal elektronik (baca: elektron) dan menyimpannya pada media penyimpanan data (memory card) dalam format data digital (binary code); dengan simbol 0 dan 1.

Baik sensor CCD maupun CMOS memiliki fungsi yang sama yaitu mengubah cahaya menjadi elektron. Untuk mengetahui cara sensor bekerja kita harus mengetahui prinsip kerja sel surya. Anggap saja sensor yang digunakan di kamera digital seperti memiliki ribuan bahkan jutaan sel surya yang kecil dalam bentuk matrik dua dimensi. Masing-masing sel akan mentransformasi cahaya dari sebagian kecil gambar yang ditangkap menjadi elektron. Kedua sensor ini melakukan pekerjaan tersebut dengan berbagai macam teknologi yang ada. Kemampuan ini dinyatakan dalam nilai resolusi.

Resolusi berkaitan dengan sensitivitas dalam menangkap cahaya menjadi faktor penting dalam menentukan kualitas produk kamera digital. Sensor CCD memerlukan proses pembuatan secara khusus untuk menciptakan kemampuan memindahkan elektron ke chip tanpa distorsi. Dalam kata lain, sensor CCD menjadi lebih baik kualitasnya dalam ketajaman dan sensitivitas cahaya. CCD terdiri dari kumpulan sel yang disebut photosite. Cahaya yang mengenai sel photosite diakumulasikan menjadi tegangan elektris oleh photo diode. Elektron akan dikonversikan menjadi bentuk digital setiap photositenya sehingga setiap pixel sepenuhnya yang membentuk gambar memiliki keseragaman maka menghasilkan kualitas gambar yang sangat tinggi. Sensor CCD tidak memiliki tronsistor pada setiap photositenya sehingga proses pengolahan data dilakukan secara eksternal.

Pada sensor CMOS terdapat transistor di setiap photosite-nya sehingga pixel memimiliki kemampuan konversi muatan listrik. Fungsi 
ini mereduksi jumlah pixel bagi penangkapan gambar karena setiap pixel melakukan konversinya masing-masing mengakibatkan keseragaman nilai output-nya lebih rendah. Namun di sisi lain, chip-nya membutuhkan lebih sedikit sirkuit. CMOS menawarkan lebih banyak integrasi, konsumsi sumber daya lebih rendah (pada level chip), ukuran sistem lebih kecil, tetapi kualitas gambar dan fleksibilitasnya lebih rendah dibanding CCD. Kemampuan produksi CMOS lebih banyak dan tidak membutuhkan ruang besar.

Hal penting lain pada kamera digital adalah tentang memory card. Kartu penyimpanan sebagai media untuk menampung hasil bidikan objek yang dikehendaki. Beberapa macam memory card yang sering digunakan pada kamera digital adalah: Compact Flash (CF) merupakan bentuk Memory Stick awal dikembangkan oleh Sandisk pada tahun 1994. Kapasitas CF mulai dari $128 \mathrm{Mb}$ sampai $8 \mathrm{~Gb}$ pada tahun 2010-an. Kemudian ada Memory Stick yang dikenalkan oleh Sony manufacturing pada tahun 1998. Berbentuk lebih kecil dari CF, namun dalam hal kecepatan Memory Stick lebih lambat dari CF. Lantas ada Smart Media yang pertama diluncurkan dikenal sebagai Solid State Floppy Disk Card (SSFDC). Ada lagi Secure Digital (SD card) yang memiliki kecepatan penyimpanan lebih cepat lagi serta dilengkapi dengan enkripsi built-in untuk memproteksi data. (Mahendra, 2010).

Kemudahan dari kamera digital adalah hasil gambar yang dengan cepat diketahui hasilnya secara instan dan kemudahan memindahkan hasil (transfer). Beberapa kamera digital, terutama DSLR dan high-end cameras dilengkapi fasilitas RAW yang dapat ditindaklanjuti di komputer menggunakan perangkat lunak tertentu untuk hasil terbaik, tetapi pada saat ini fasilitas Auto Mode telah menghasilkan gambar yang baik dalam format JPEG.

Dari berbagai pembacaan yang penulis temukan terdapat banyak sekali macam dan jenis kamera digital. Untuk membantu memberikan gambaran tentang berbagai macam kamera digital berikut saya sampaikan tulisan dari Enche Tjin yang terdapat dalam Panduan lengkap memilih kamera digital di laman infofotografi.com. Tjin menyebut ponsel, Kamera compact/ saku, Kamera kompak canggih (advanced compact), Kamera prosumer atau 
superzoom, Mirrorless, Kamera DSLR pemula, Kamera DSLR menengahcanggih, dan Kamera DSLR PRO.

Dari sekian banyak macam kamera digital, tidak ada yang mampu mengalahkan popularitas kamera smartphone. Hal ini dapat dirujuk kepada penerimaan masyarakat luas terhadap kamera digital smartphone. Salah satu efek samping dari kenaikan popularitas smartphone adalah penurunan penjualan kamera kompak/digital. Kita bisa menemukan judul berita seperti ini: Gara-gara Smartphone, Penjualan Kamera Digital Stagnan di Indonesia (infokomputer.grid.id, tertanggal 27 Februari 2019). Survei yang dikeluarkan oleh Consumer Electronics Association (CEA) dengan meneliti sebanyak 1.001 orang di Amerika Serikat; mengindikasikan bahwa kamera digital kelas pointand-shoot atau compact masih menjadi piranti utama untuk motret, namun angkanya diketahui menurun. Di sisi lain, mereka yang mengatakan bahwa smartphone adalah piranti utama untuk motret, angkanya naik dari tahun ke tahun (inet.detik.com). Ini tidak terlepas dengan tingkat kepemilikan smartphone tentunya. Pada paruh awal tahun 2019 diperkirakan lebih dari 5 miliar orang memiliki ponsel, dan separuh lebih adalah berupa ponsel pintar atau smartphone.

Berbagai alasan mengapa orang memilih kamera smartphone. Pertama adalah soal kenyamanan dalam menggunakan kamera smartphone dibanding kamera digital konvensional. Sangat tidak mungkin orang akan meninggalkan rumah dengan membawa kamera digital setiap hari, sementara kamera smartphone mudah dibawa, kecuali dia seorang fotografer profesional.

Mayoritas kamera smartphone modern dapat dengan mudah terhubung ke internet, entah dengan paket data maupun WiFi. Setelah terhubung dengan internet, sangat memungkinkan dapat berbagi foto dari smartphone tersebut dalam hitungan detik, melalui pesan teks, dengan melampirkannya ke email, atau mempostingnya ke Facebook. Sharing dari kamera digital sedikit lebih rumit, karena mengharuskan untuk memakai kabel USB atau kartu memori; menambah bawaan perangkat ke mana-mana disamping itu juga harus memiliki akses ke komputer. Problematika ini disederhanakan oleh hadirnya kamera smartphone. 
Salah satu alternatifnya adalah memiliki kamera dengan fitur WiFi yang disebut Smart Camera, yang dibuat oleh produsen seperti Canon, Panasonic, dan Samsung ini memberikan kemungkinan untuk aktivitas mengunggah foto ke situs penyimpanan foto atau media sosial dan terhubung ke aplikasi smartphone khusus. Namun opsi berbagi ini tidak begitu lengkap seperti halnya yang ditawarkan oleh smartphone, yang dapat mencakup solusi instan seperti SMS, Facebook/Messenger, Skype, dan solusi penyimpanan awan seperti WhatsApp, Dropbox, Google Drive, dan lainnya. Sebagaimana ditulis oleh Sadono (2015: 7): Kehadiran smartphone dengan feature kamera di dalamnya tidak bisa lagi dipandang sebelah mata. Feature kamera dari smartphone secara kualitas bahkan sudah bisa mengalahkan hasil dari kamera saku di kelas low-end. Selain praktis, salah satu keunggulan dari smartphone adalah banyaknya pilihan aplikasi pengolah foto yang bisa digunakan untuk merekayasa dan memperbaiki kualitas gambar langsung dari peranti tersebut. Aplikasi-aplikasi tersebut umumnya bisa diunduh secara gratis dari Google Play Store.

Disamping hal tersebut kelebihan lainnya adalah bahwa tersedia ratusan bahkan ribuan aplikasi smartphone yang didedikasikan untuk fotografi, aplikasi-aplikasi ini memberikan beragam fasilitas editing foto seperti mengubah eksposure dan menambahkan bingkai (Snapseed), menambahkan filter (Instagram), menghapus warna (Cloud Splash FX), dan bahkan membuat film gerak lambat (Slow Pro). Hal ini membuat ide kreatifitas menjadi lebih mudah mengalir dan bereksperimen dengan fotofoto hasil bidikan di dalam smartphone itu sendiri. Dan yang tak mudah untuk dikesampingkan adalah faktor harga, kini bahkan ponsel murah di rentang harga 3 juta ke bawah mulai memperbaiki aspek kamera dan hasilnya sudah cukup oke, bahkan ada juga yang pakai dua lensa di ponsel ekonomis ini.

\section{B. Perpustakaan dan Pemustaka}

Perpustakaan, pemustaka dan informasi membentuk ekosistem ilmu pengetahuan. Sebagai fondasi peradaban manusia. Mengunjungi perpustakaan setara dengan wisata ke destinasi arsitektur pengetahuan. 
Membaca bahan pustaka yang tersedia di perpustakaan bagaikan menjelah ruang demi ruang, pilar demi pilar, dinding, hamparan lantai, dan sebagainya. Sensasi yang muncul akan memberikan pengalaman estetis yang memperkaya batin. Begitulah gambarannya jika membaca bahan pustaka di perpustakaan yang perbendaharaannya sangat luar biasa. Perpustakaan merupakan instrumen penting untuk mewujudkan potensi besar dari pengetahuan yang terkandung dalam media penyimpan pengetahuan baik dalam buku, sebelum dan sesudah tablet tanah liat, papirus, perkamen, lontar, manuskrip, sampai dalam format portable document format (PDF). Memasuki perpustakaan mengantarkan orang ke dalam kekuatan yang tiada tanding. Menyelami kedalaman palung pemikiran dan penelitian sesuai pilihan. Menerjemahkan diri ke waktu dan tempat yang ingin dijalani. Tidak terbelenggu dogma tunggal, namun merdeka di atas kerajaan pengetahuan. Perpustakaan 1.000 buku yang disatukan menyajikan faedah yang jauh berbeda daripada yang bisa dipersembahkan oleh 1.000 buku di tempat terpisah. Dalam perpustakaan terjalin komunikasi pengetahuan tidak hanya dari satu orang ke orang lain, dari satu budaya ke budaya yang lain, tapi dari satu generasi ke generasi yang lain. Khazanah bahan pustaka menyatukan pemahaman yang menghubungkan dan memungkinkan berbagai generasi berbagi pengalaman manusia dari waktu ke waktu dan mewujudkan visi hidup manusia ke masa yang jauh. Sekali lagi, perpustakaan adalah instrumen penting untuk mengejawantahkan potensi pengetahuan untuk keabadian.

Dengan formulasi lain dialektika perpustakaan, pemustaka dan informasi ini terungkapkan dalam buku Pengantar Ilmu Perpustakaan Sulistyo-Basuki, (1999:25-26) yang menulis bahwa: "perpustakaan mencerminkan kebutuhan sosial, ekonomi, kultural dan pendidikan suatu masyarakat". Bila kebutuhan dipenuhi maka masyarakat akan menuntut pembangunan perpustakaan. Merujuk kepada sejarah peradaban-peradaban besar manusia maka "DNA" perpustakaan itu akan dapat kita kenali dan temukan tersematkan di sana.

Pada masa budaya lisan, pengetahuan disimpan dan dikomunikasikan dengan syair, ungkapan, mantra, pepatah, folklor, mitos, cerita, atau legenda. 
Saat manusia mengenal aksara, pengetahuan disimpan dalam benda-benda yang dapat ditulisi. Bahan pustaka masih terbatas lempeng tanah liat (clay tablets) dan berkembang perlahan dengan bahan-bahan lain yang bisa ditulisi, seperti papirus, perkamen, dan vellum. Merunut sejarah, "DNA" (gen pembawa sifat) perpustakaan muncul sekitar tahun 2000 SM di Sumeria, Mesopotamia, Mesir. Kala itu perpustakaan merupakan bagian dari sebuah institusi, bisa bagian dari kuil, candi, atau bagian dari perguruan/perdikan. Perpustakaan sebagai penyimpan pengetahuan hanya dapat diakses oleh sekelompok pemakai terbatas. Hadirnya mesin cetak karya Gutenberg pada pertengahan abad ke-15 serta penemuan kertas sebagai bahan pustaka menjadikan buku cetak sebagai media pengetahuan utama (Setiyono, 2017) Pengetahuan mendapatkan media penyebaran baru yang lebih luas cakupannya dan lebih cepat. Perpustakaan mengalami perkembangan dan semakin kukuh eksistensinya. Layanan perpustakaan kepada masyarakat semakin kukuh fondasinya ketika perpustakaan melengkapi diri dengan sistem katalog dan klasifikasi. Dewey Decimal Classification (DDC) dan Anglo-American Cataloguing Rules (AACR) menjadi pedoman penting dalam pengelolaan perpustakaan. Evolusi perpustakaan memasuki babak baru ketika teknologi komputer muncul. Pengetahuan manusia mulai dicatat ke dalam format digital, bit-bit data telah mengambil dan melengkapi fungsi tinta dan pena. Otomasi dan digitalisasi menjadi rutinitas pekerjaan baru di perpustakaan, namun sebagai pranata sosial fungsi dasar perpustakaan untuk mengelola khazanah pengetahuan adalah terus melekat dalam setiap masa; sejak dari zaman tablet tanah liat (clay tablets), papirus, perkamen, kertas manuskrip, buku cetak, sampai tablet iPad, dan era PDF.

Perpustakaan dalam matra ruang dapat tumbuh dari berbagai macam ukuran cakupan kerja atau wilayah yang menjadi pokok target layanan perpustakaan. Perpustakaan bisa hadir mulai dari lingkup desa, institusi-institusi, kota, sampai lingkup negara. Perpustakaan juga dapat hadir sebagai prakarsa dari komunitas, sebagai Taman Bacaan. Perpustakaan bisa hadir melayani masyarakat desa atau kelurahan, melayani siswa-siswi di sekolahan, melayani para mahasiswa di kampus-kampus. Perpustakaan 
juga bisa hadir secara bergerak dengan konsep perpustakaan keliling. Kalau merujuk kepada Undang-Undang Republik Indonesia Perpustakaan Nomor 43 Tahun 2007 kita dapat menyebutkan jenis-jenis perpustakaan yaitu terdiri atas: Perpustakaan Nasional, Perpustakaan Umum, Perpustakaan Sekolah/ Madrasah, Perpustakaan Perguruan Tinggi; dan Perpustakaan Khusus. Demikian bunyi pasal 20 dalam Undang-Undang tersebut.

Selanjutnya, pemustaka ialah pengguna fasilitas yang disediakan perpustakaan, baik koleksi maupun buku (bahan pustaka maupun fasilitas lainnya). Ada berbagai jenis pemustaka seperti pelajar, mahasiswa, guru, dosen, karyawan dan masyarakat umum, tergantung dengan jenis perpustakaan tersebut (Suwarno, 2009: 80). Pengertian pemustaka menurut UU Nomor 43 tahun 2007 tentang perpustakaan pasal 1 ayat 9 ialah pengguna perpustakaan, yaitu perseorangan, kelompok orang, masyarakat atau lembaga yang memanfaatkan fasilitas layanan perpustakaan.

Dapat disimpulkan bahwa pemustaka ialah pengguna perpustakaan, baik perseorangan maupun kelompok yang memanfaatkan layanan, fasilitas dan koleksi yang tersedia di perpustakaan. Sangat beruntung dalam bahasa Indonesia terdapat istilah pemustaka untuk mengidentifikasikan pemakai atau pengguna perpustakaan. Pemustaka mendapat penamaan yang ringkas dan padat namun cukup indikatif, mewakili obyek secara langsung dan mengurangi bias terhadap pengertian lain. Tidak seperti kepustakawanan di benua lain seperti Amerika dan Eropa yang berbahasa Inggris, mereka galau ketika harus merujuk pemustaka. Sebagaimana diungkapkan oleh Bob McKee berikut ini: "Some librarians shy away from the term 'customer' because it hints at commerce (customers pay for things). But there are problematic connotations with many of the terms used by librarians to refer to the people who use -or migth use- their services". (McKee, 1989:1).

Pemustaka menjadi faktor yang tidak bisa diabaikan begitu saja dalam setiap program dan kegiatan pengelolaan layanan perpustakaan. Pemustaka senantiasa menjadi salah satu variabel yang memiliki pengaruh dalam dinamika perpustakaan. Untuk itu perpustakaan wajib senantiasa "mendengarkan" dan memperhatikan pemustakanya. Aspirasi pemustaka 
baik itu hadirnya dari kotak saran, media sosial, e-mail, survei, maupun komunikasi langsung merupakan input berharga dalam memperbaiki serta meningkatkan kualitas layanan perpustakaan.

\section{Bahan Pustaka}

Undang-Undang Republik Indonesia Perpustakaan No 43 tahun 2007 pasal 1 ayat 2 menyatakan bahwa Koleksi perpustakaan adalah semua informasi dalam bentuk karya tulis, karya cetak, dan/atau karya rekam dalam berbagai media yang mempunyai nilai pendidikan, yang dihimpun, diolah, dan dilayankan. Dalam ayat 10 disebutkan pula bahwa Bahan perpustakaan adalah semua hasil karya tulis, karya cetak, dan/atau karya rekam. Pendapat lain menyebutkan Koleksi bahan pustaka menurut Suwarno (2009:41), yaitu: Sejumlah bahan pustaka yang telah ada di perpustakaan dan telah diolah (diproses), sehingga siap dipinjamkan atau digunakan oleh pemakai.

Ada banyak jenis koleksi bahan pustaka yang disediakan oleh perpustakaan seperti terbitan pemerintah; terbitan perguruan tinggi; terbitan badan internasional; bahan referensi; dan bahan non buku lainnya. Namun buku menjadi bahan pustaka yang populer bagi pemustaka. Berdasarkan standar dari UNESCO tebal buku paling sedikit setidaknya terdiri dari 49 halaman, tidak termasuk kulit maupun jaket buku, contohnya buku fiksi, buku teks, dan buku rujukan. Konsep anatomi buku. Yaitu menyangkut bagian-bagian buku yang harus tercantum, serta bagian yang sifatnya boleh tercantum boleh tidak (opsional). Buku sejatinya terbagi atas tiga bagian besar yang disebut 1) bagian pendahuluan (preliminaries/front matter); 2) bagian isi (text matter); 3) bagian penyudah (postliminaries/back matter). Selain itu, ada bagian luar yang disebut cover buku, terdiri atas cover depan (front cover), cover belakang (back cover), dan punggung buku (spine), dikutip dari Bambang Trim dalam laman InstitutPenulis.id. Tiap bagian mengandung lagi subbagian atau sering disebut sebagai halaman.

Anatomi buku selanjutnya menjadi panduan untuk mencatat atau meringkas isi kandungan informasi yang diperlukan oleh pemustaka. Dalam blog.ruangguru.com mengemukakan: Cara-cara mencatat mendapat 
pengembangan atau penguatan dalam segi kesederhanaan dan kecepatannya. Metode Cornell adalah salah satu contoh metode mencatat itu. Metode Cornell sudah diciptakan sejak tahun 1950-an oleh Prof. Walter Pauk dari Cornell University. Metode ini secara umum adalah strategi pembagian bidang untuk mencatat. Secara spasial seluruh bidang catatan dibagi menjadi tiga bagian dengan fungsinya masing-masing. Pertama, ada bidang untuk mencatat mengenai ide utama (main idea), kata kunci (keyword), pertanyaan utama, penjuru atau isyarat (cues). Kedua, ada bidang untuk membuat catatan secara lebih mendetail, atau untuk menulis catatan yang diperlukan tentang hal-hal yang berada pada bagian atau bidang pertama tadi. Ketiga, adalah bidang untuk menuliskan kesimpulan (summary).

\section{Disrupsi}

Disrupsi kini sedang menjadi tema perbincangan yang hangat. Bahkan saat ini disebut-sebut sebagai era disrupsi. Era disrupsi terjadi ketika suatu inovasi baru masuk ke pasar dan menciptakan efek pergeseran yang cukup kuat sehingga mengubah struktur pasar yang sebelumnya. Dalam kamus besar Bahasa Indonesia, disrupsi didefinisikan hal tercabut dari akarnya (KBBI, 2017: 398). Dalam kehidupan sehari-hari, disrupsi diartikan keadaan atau situasi yang sedang terjadi perubahan fundamental serta mendasar. Istilah disrupsi pertama kali dipopulerkan oleh Clayton M. Christensen, profesor Administrasi Bisnis dari Universitas Harvard. Christensen menyebut disrupsi sebagai sebuah perubahan besar yang membuat industri tidak berjalan seperti biasa, umumnya karena penemuan teknologi. Perubahan itu memunculkan pemain-pemain baru dan membuat pemain bisnis lama harus memikirkan ulang strategi berhadapan dengan era baru ini. Apabila evaluasi ini tidak dilakukan maka pelan dan perlahan eksistensi bisnis akan mengalami proses surut bahkan tidak menutup kemungkinan untuk mengalami tenggelam. Disrupsi mengakibat perubahan yang begitu cepat terjadi. Tren perkembangan teknologi bergeser sehingga perusahaan teknologi digital menjadi pemain puncak ekosistem dan ekonomi dunia. 
Pada era disrupsi ini merupakan fenomena ketika masyarakat menggeser aktivitas-aktivitas yang awalnya dilakukan di dunia nyata beralih ke dunia maya. Fenomena ini menggejala dan terus berkembang memicu dan memacu perubahan pola-pola dunia bisnis. Sebut saja contohnya kemunculan transportasi berbasis online atau daring via gadget adalah salah satu yang paling populer berdampak di negeri kita Indonesia. Alarm tentang disrupsi sejatinya telah mulai dibunyikan oleh Alvin Toffler (1980) seorang futurolog yang dikenal karena karyanya banyak mengulas tentang revolusi telekomunikasi serta tentang teknologi digital; ia menyampaikan bahwa dunia telah memasuki perubahan gelombang ketiga, setelah revolusi pertanian ke revolusi industri maka revolusi yang dihadapi adalah revolusi informasi. Era informasi menjadi pengerak disrupsi teknologi. Disrupsi beroperasi menggantikan teknologi-teknologi lama yang menekankan sisi fisikal berganti dengan teknologi digital yang benar-benar baru, lebih efisien, dan lebih bermanfaat.

Merujuk kepada pernyataan Kasali (2017:17) disrupsi ditandai dengan empat indikator, yaitu lebih mudah (simpler), lebih murah (cheaper), lebih terjangkau (accessible), dan lebih cepat (faster).

\section{METODE}

Penelitian ini merupakan deskriptif yang menggunakan pendekatan kuantitatif. Penelitian dilaksanakan selama enam bulan pada Mei sampai Oktober 2019. Populasi dalam penelitian ini adalah anggota UPT Perpustakaan ISI Surakarta yang masih berstatus aktif dalam tahun ajaran 2019/2020, serta dari anggota mahasiswa jenjang strata satu (S1). Ukuran sampel adalah 10\% dari populasi sebagaimana rumusan besaran sampel yang dikemukakan oleh Arikunto (1985:94) yaitu untuk sekedar ancer-ancer maka apabila subjek penelitian kurang dari 100, lebih baik diambil semua sehingga penelitiannya merupakan penelitian populasi. Selanjutnya jika jumlah subjeknya besar dapat diambil antara 10-15\%, atau 20-25\% atau lebih. Teknik pengambilan sampel penelitian ini menggunakan random sampling. Pengumpulan data utamanya dengan menggunakan kuesioner; ditambah dengan observasi, 
wawancara dan dokumentasi.

Analisis data yang digunakan dalam penelitian ini yaitu: Uji validitas dan reliabilitas, kemudian pengukuran skala likert terhadap semua variabel penelitian dilanjutkan dengan penghitungan mean dan grand mean. Pengujian validitas digunakan untuk mengukur validitas instrumen penelitian yang digunakan dalam pengumpulan data. Pengujian reliabilitas digunakan untuk mengukur tingkat kepercayaan instrumen penelitian. Skala likert digunakan untuk mengklasifikasikan variabel yang akan diukur supaya tidak terjadi kesalahan dalam menentukan analisis data dan langkah selanjutnya (Azwar,2012: 37). Prinsip pokok skala likert adalah menentukan lokasi kedudukan seseorang dalam suatu kontinum sikap terhadap objek sikap, mulai dari sangat negatif sampai sangat positif. Adapun dalam penelitian ini menggunakan skala 5 dari skala likert yaitu menyediakan lima alternatif jawaban yaitu Sangat Setuju (SS), Setuju (S), Kurang Setuju (KS) Tidak Setuju (TS), dan Sangat Tidak Setuju (STS). Besaran nilainya adalah: $\mathrm{SS}=5, \mathrm{~S}=4, \mathrm{KS}=3, \mathrm{TS}=2, \mathrm{STS}=1$.

\section{HASIL DAN PEMBAHASAN}

\section{A. Profil Pemustaka}

Pemustaka yang menjadi populasi dalam penelitian ini adalah mahasiswa strata satu (S1) yang menjadi anggota UPT Perpustakaan ISI Surakarta. Pemustaka sebanyak 1.443 terdiri dari mahasiswa Fakultas Seni Pertunjukan (FSP) sebanyak 763 dan mahasiswa Fakultas Seni Rupa dan Desain (FSRD) sebanyak 680 mahasiswa. Namun mengacu kepada rumusan mengenai besaran sampel yang dikemukakan oleh Arikunto (1985:94) yaitu untuk sekedar ancer-ancer maka apabila subjek penelitian kurang dari 100, lebih baik diambil semua sehingga penelitiannya merupakan penelitian populasi. Selanjutnya jika jumlah subjeknya besar dapat diambil antara 10-15\%, atau 20-25\% atau lebih. Sampel yang diambil sebesar 10\% dari jumlah populasi. Sehingga terpilih sampel sebanyak 144 pemustaka sebagai responden. 
Selengkapnya profil responden pemustaka adalah sebagai berikut: Mahasiswa FSP sebanyak 73 atau (51\%) sedang mahasiswa FSRD sebanyak 71 atau (49\%). Kemudian dari jenis kelamin responden laki-laki sebanyak 53 (37\%) dan responden perempuan sebanyak 91 atau (63\%).

Komposisi pemustaka berdasar program studi (prodi) yaitu: Secara umum dapat dibaca bahwa responden terbanyak berasal dari prodi Seni Tari sebanyak 32 pemustaka menempati $22 \%$ responden. Kemudian dari prodi Televisi dan Film berada di urutan kedua dengan jumlah 23 pemustaka atau 16\% responden; disusul prodi Karawitan dengan 17 pemustaka menempati $12 \%$ responden. Komposisi responden penelitian dibedakan dari tahun masuk/angkatan para pemustaka sebagai mahasiswa. Dapat dibaca bahwa pemustaka terbanyak berasal dari tahun masuk/angkatan 2015 sebanyak 67 pemustaka menempati 46\% responden. Kemudian dari tahun masuk/ angkatan 2014 berada di urutan kedua dengan jumlah 26 pemustaka atau 18\% responden; disusul dari tahun masuk/angkatan 2017 dengan 11 pemustaka menempati $8 \%$ responden. Selengkapnya mengenai profil pemustaka dapat dilihat pada gambar infografis di bawah ini:

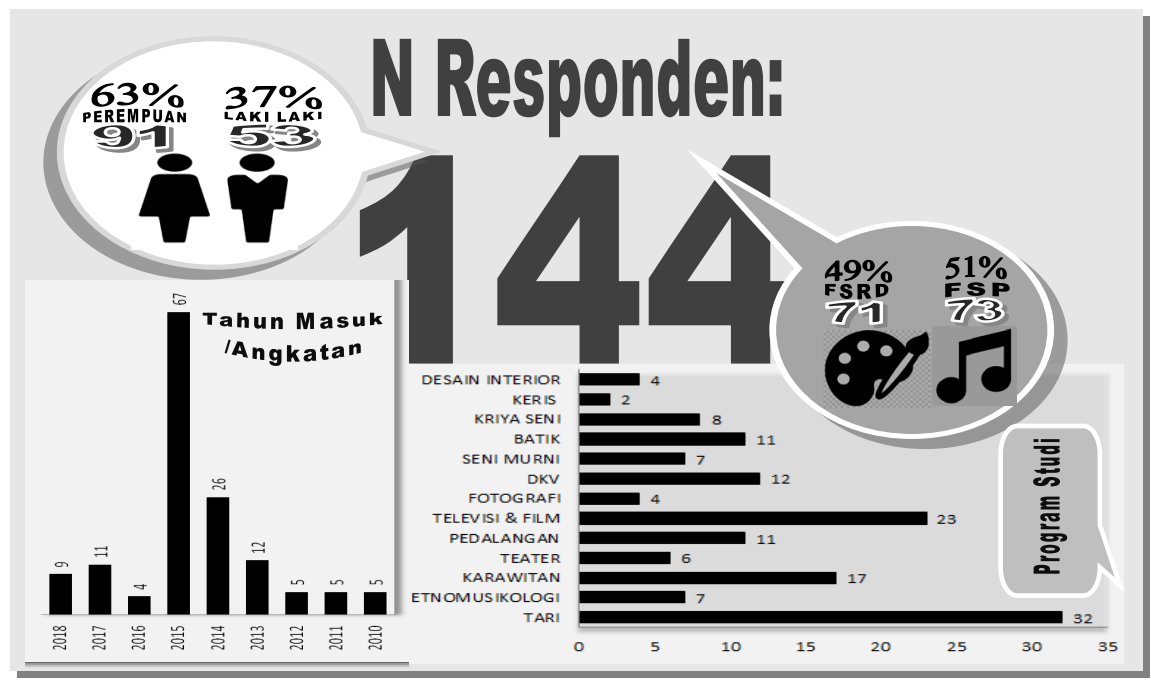

Gambar 1. Infografis Profil Pemustaka

Sumber Setiyono (2019:28) 


\section{B. Validitas dan Reliabilitas}

Uji validitas dan reliabilitas ini menggunakan sampel 144 responden dengan tingkat signifikansi 5\% (0,05). Pertanyaan variabel Pemanfaatan Kamera Digital oleh Pemustaka dibagi menjadi tiga sub variabel selanjutnya memiliki 10 (sepuluh) indikator sebagai butir pertanyaan, berdasarkan hasil uji validitas seluruh item pertanyaan adalah valid dengan nilai tingkat signifikan $<0,05$. Item pertanyaan yang layak untuk dianalisis sebanyak 10 pertanyaan, atau dengan kata lain seluruh item pertanyaan adalah memiliki validitas. Kemudian untuk uji reliabilitas menunjukan bahwa berdasarkan hasil analisis reliabilitas diperoleh besarnya koefisien reliabilitas Alpha = 0,981. Oleh karena nilai Cronbach Alpha > 0,60 maka variabel Pemanfaatan Kamera Digital oleh Pemustaka dapat dinyatakan reliabel dan layak digunakan untuk dianalisis. Selengkapnya dapat dilihat pada Tabel 1. di bawah ini:

\section{Tabel 1. Uji Validitas dan Reliabilitas variabel Pemanfaatan Kamera Digital}

\begin{tabular}{|c|c|c|c|c|c|c|}
\hline Variabel & Sub variabel & Indikator & $\mathbf{R}$ & R Tabel & Sig & Ket \\
\hline \multirow[t]{4}{*}{$\begin{array}{l}\text { Pemanfaatan } \\
\text { Kamera } \\
\text { Digital oleh } \\
\text { Pemustaka( }\end{array}$} & $\begin{array}{l}\text { Kepemilikan } \\
\text { Kamera } \\
\text { Digital }\end{array}$ & $\begin{array}{l}\text { 1. Saya memiliki beberapa } \\
\text { macam kamera digital } \\
\text { (kamera saku, prosumer, } \\
\text { mirrorless, DSLR, kamera } \\
\text { smartphone/handphone) }\end{array}$ & 0,897 & 0,1637 & 0,000 & Valid \\
\hline & & $\begin{array}{l}\text { 2. Saya memiliki kamera } \\
\text { smartphone/handphone } \\
\text { saja. }\end{array}$ & 0,947 & 0,1637 & 0,000 & Valid \\
\hline & & $\begin{array}{l}\text { 3. Saya memiliki kamera } \\
\text { digital sejak usia sekolah. }\end{array}$ & 0,953 & 0,1637 & 0,000 & Valid \\
\hline & $\begin{array}{l}\text { Pemanfaatan } \\
\text { Kamera } \\
\text { Digital }\end{array}$ & $\begin{array}{l}\text { 4. Saya memotret informasi } \\
\text { main idea (ide utama, } \\
\text { topik bahasan, konsep, } \\
\text { teori, uraian tambahan, ide } \\
\text { pendukung) sebagai cara } \\
\text { mencatatnya. }\end{array}$ & 0,949 & 0,1637 & 0,000 & Valid \\
\hline
\end{tabular}




\begin{tabular}{|c|c|c|c|c|c|c|}
\hline Variabel & Sub variabel & Indikator & $\mathbf{R}$ & R Tabel & Sig & Ket \\
\hline & & $\begin{array}{l}\text { 5. Saya memotret informasi } \\
\text { supporting detail.(penga- } \\
\text { rang, judul, penerbit, tahun } \\
\text { terbit, cover buku, kata } \\
\text { kunci, daftar isi, daftar pus- } \\
\text { taka, singkatan atau simbol) } \\
\text { sebagai cara mencatatnya. }\end{array}$ & 0,945 & 0,1637 & 0,000 & Valid \\
\hline & & $\begin{array}{l}\text { 6. Saya memotret informasi } \\
\text { summaries (ringkasan, abs- } \\
\text { trak, kesimpulan, penutup) } \\
\text { sebagai cara mencatatnya. }\end{array}$ & 0,943 & 0,1637 & 0,000 & Valid \\
\hline & $\begin{array}{l}\text { Disrupsi } \\
\text { Kamera } \\
\text { Digital }\end{array}$ & $\begin{array}{l}\text { 7. Bagi saya mencatat infor- } \\
\text { masi dengan kamera digital } \\
\text { menjadi lebih mudah } \\
\text { (simpler). }\end{array}$ & 0,948 & 0,1637 & 0,000 & Valid \\
\hline & & $\begin{array}{l}\text { 8. Bagi saya mencatat infor- } \\
\text { masi dengan kamera digital } \\
\text { menjadi lebih murah } \\
\text { (cheaper). }\end{array}$ & 0,943 & 0,1637 & 0,000 & Valid \\
\hline & & $\begin{array}{l}\text { 9. Bagi saya mencatat } \\
\text { informasi dengan kamera } \\
\text { digital menjadi lebih } \\
\text { terjangkau (accessible) }\end{array}$ & 0,935 & 0,1637 & 0,000 & Valid \\
\hline & & $\begin{array}{l}\text { 10. Bagi saya mencatat infor- } \\
\text { masi dengan kamera di- } \\
\text { gital menjadi lebih cepat } \\
\text { (faster). }\end{array}$ & 0,917 & 0,1637 & 0,000 & Valid \\
\hline $\begin{array}{l}\text { Cronbach } \\
\text { Alpha }\end{array}$ & 0,60 & Nilai Cronbach Alpha & 0,981 & \multicolumn{2}{|c|}{$0,981>060$} & Reliabel \\
\hline
\end{tabular}

\section{Kepemilikan Kamera Digital}

Deskripsi tentang kepemilikan kamera digital dari pemustaka dapat dilihat dari nilai jawaban pada sub variabel kepemilikan kamera digital yaitu: Indikator pertama; saya memiliki beberapa macam kamera digital (kamera saku, prosumer, mirrorless, DSLR, kamera smartphone/handphone) pemustaka atau responden sejumlah 18 (12\%) menjawab sangat setuju, 46 (32\%) responden menjawab setuju, 23 (16\%) responden menjawab kurang setuju, 54 (38\%) responden menjawab tidak setuju dan 3 (2\%) responden menjawab sangat tidak setuju. Nilai rata-rata sebesar 2,993 yaitu berada pada 
rentang 2,60 - 3,40 yang berarti nilai pernyataan "Saya memiliki beberapa macam kamera digital (kamera saku, prosumer, mirrorless, DSLR, kamera smartphone/handphone)" berarti ada pada tingkat sedang.

Indikator kedua yaitu: "Saya memiliki kamera smartphone / handphone saja” pemustaka menunjukkan bahwa: 46 (32\%) responden menjawab sangat setuju, 34 (24\%) responden menjawab setuju, 44 (31\%) responden menjawab kurang setuju, 18 (12\%) responden menjawab tidak setuju dan 2 (1\%) responden menjawab sangat tidak setuju. Akumulasi jawaban ini menghasilkan nilai rata-rata sebesar 3,722 yaitu berada pada rentang 3,40 - 4,20 yang berarti responden menilai pernyataan "Saya memiliki memiliki kamera smartphone / handphone saja dengan tingkat yang tinggi.

Indikator ketiga yaitu "Saya memiliki kamera digital sejak usia sekolah.” Umumnya enggan atau ragu-ragu untuk mengungkapkannya. Karena dari data terhadap pernyataan ini adalah: 10 (7\%) responden menjawab sangat setuju, 45 (31\%) responden menjawab setuju, 47 (33\%) responden menjawab kurang setuju, 29 (20\%) responden menjawab tidak setuju dan 13 (9\%) responden menjawab sangat tidak setuju. Sehingga menghasilkan nilai rata-rata sebesar 3,069 yaitu berada pada rentang 2,60 - 3,40 yang berarti responden menilai pernyataan "Saya memiliki kamera digital sejak usia sekolah" dengan tingkat yang sedang. Paling banyak pemustaka menjawab kurang setuju (KS).

Selengkapnya nilai penghitungan, persentase dan mean dari ketiga indikator dapat dilihat pada tabel 1 di bawah ini:

\section{Tabel 2. Kepemilikan Kamera Digital}

\begin{tabular}{|c|c|c|c|c|c|c|c|c|}
\hline $\begin{array}{c}\text { Sub } \\
\text { Variabel }\end{array}$ & Indikator & $\operatorname{STS}(1)$ & $\mathrm{TS}(2)$ & $\mathrm{KS}(3)$ & $S(4)$ & SS(5) & Jumlah & Mean \\
\hline $\begin{array}{l}\text { Kepemi- } \\
\text { likan } \\
\text { Kamera } \\
\text { Digital }\end{array}$ & $\begin{array}{l}\text { 1. Saya memiliki bebe- } \\
\text { rapa macam kamera } \\
\text { digital (kamera saku, } \\
\text { prosumer, mirror- } \\
\text { less, DSLR, kamera } \\
\text { smartphone/handphone) }\end{array}$ & $\begin{array}{c}3 \\
2 \% \\
3\end{array}$ & $\begin{array}{c}54 \\
38 \% \\
108\end{array}$ & $\begin{array}{c}23 \\
16 \% \\
48\end{array}$ & $\begin{array}{c}46 \\
32 \% \\
184\end{array}$ & $\begin{array}{c}18 \\
12 \% \\
90\end{array}$ & $\begin{array}{c}144 \\
100 \% \\
\Sigma X 431\end{array}$ & 2,993 \\
\hline
\end{tabular}




\begin{tabular}{clccccccc}
\hline $\begin{array}{c}\text { Sub } \\
\text { Variabel }\end{array}$ & \multicolumn{1}{c}{ Indikator } & STS(1) & TS(2) & KS(3) & S(4) & SS(5) & Jumlah & Mean \\
\hline & 2. Saya memiliki kamera & 2 & 18 & 44 & 34 & 46 & 144 & 3,722 \\
& smartphone/hand- & $1 \%$ & $12 \%$ & $32 \%$ & $24 \%$ & $32 \%$ & $100 \%$ & \\
& phone saja. & 2 & 36 & 132 & 136 & 230 & $\sum X 536$ & \\
\hline & 3. Saya memiliki kamera & 13 & 29 & 47 & 45 & 10 & 144 & 3,069 \\
& digital sejak usia & $9 \%$ & $20 \%$ & $33 \%$ & $31 \%$ & $7 \%$ & $100 \%$ & \\
& sekolah. & 13 & 58 & 141 & 180 & 50 & $\sum X 442$ & \\
\hline
\end{tabular}

\section{Pemanfaatan Kamera Digital}

Deskripsi tentang pemanfaatan kamera digital oleh pemustaka dapat menunjukan data-data berikut ini: Pada indikator keempat yaitu "Saya memotret informasi main idea (ide utama, topik bahasan, konsep, teori, uraian tambahan, ide pendukung) sebagai cara mencatatnya" pemustaka/ responden sejumlah 1 (1\%) menjawab sangat tidak setuju, $9(6 \%)$ responden menjawab tidak setuju, 34 (24\%) responden menjawab kurang setuju, 72 (50\%) responden menjawab setuju, dan 28 (19\%) responden menjawab sangat setuju. Sehingga menghasilkan rata-rata 3,812 nilai ini berada pada rentang 3,40 - 4,20 yang berarti responden memberikan nilai kepada pernyataan "Saya memotret informasi main idea (ide utama, topik bahasan, konsep, teori, uraian tambahan, ide pendukung) sebagai cara mencatatnya" dengan tingkat yang tinggi.

Pada indikator kelima yaitu: "Saya memotret informasi supporting details (pengarang, judul, penerbit, tahun terbit, cover buku, kata kunci, daftar isi, daftar pustaka, singkatan atau simbol) sebagai cara mencatatnya" diketahui bahwa 10 (7\%) responden menjawab tidak setuju, 17 (12\%) responden menjawab kurang setuju, 79 (55\%) responden menjawab setuju, dan 38 (26\%) responden menjawab sangat setuju. Sehingga menghasilkan rata-rata 4,006 yaitu berada pada rentang 3,40 - 4,20 yang berarti responden menilai pernyataan "Saya memotret informasi supporting details (pengarang, judul, penerbit, tahun terbit, cover buku, kata kunci, daftar isi, daftar pustaka, singkatan atau simbol) sebagai cara mencatatnya" dengan tingkat yang tinggi.

Lalu pada indikator/pernyataan keenam yaitu: "Saya memotret informasi summaries (ringkasan, abstrak, kesimpulan, penutup) sebagai cara 
mencatatnya"; diketahui bahwa 11 (8\%) pemustaka/responden menjawab tidak setuju, 33 (23\%) responden menjawab kurang setuju, 74 (51\%) responden menjawab setuju, dan 26 (18\%) responden menjawab sangat setuju sehingga menghasilkan rata-rata 3,798 yaitu berada pada rentang 3,40 - 4,20 yang berarti responden menilai pernyataan "Saya memotret informasi summaries (ringkasan, abstrak, kesimpulan, penutup) sebagai cara mencatatnya" dengan tingkat yang tinggi.

Pada ketiga indikator tersebut skor tertinggi diperoleh pada pernyataan "Saya memotret informasi supporting details (pengarang, judul, penerbit, tahun terbit, cover buku, kata kunci, daftar isi, daftar pustaka, singkatan atau simbol) sebagai cara mencatatnya" dengan nilai 4,006. Skor terendah terdapat pada pernyataan "Saya memotret informasi summaries (ringkasan, abstrak, kesimpulan, penutup) sebagai cara mencatatnya” dengan nilai 3,798. Selengkapnya dapat dilihat pada Tabel 3 berikut ini:

\section{Tabel 3. Pemanfaatan Kamera Digital}

\begin{tabular}{|c|c|c|c|c|c|c|c|c|}
\hline $\begin{array}{c}\text { Sub } \\
\text { Variabel }\end{array}$ & Indikator & STS (1) & TS (2) & KS (3) & $S(4)$ & SS (5) & Jumlah & Mean \\
\hline \multirow[t]{3}{*}{$\begin{array}{l}\text { Peman- } \\
\text { faatan } \\
\text { Kamera } \\
\text { Digital }\end{array}$} & $\begin{array}{l}\text { 4. Saya memotret informasi } \\
\text { main idea (ide utama, } \\
\text { topik bahasan, konsep, } \\
\text { teori, uraian tambahan, } \\
\text { ide pendukung) sebagai } \\
\text { cara mencatatnya. } \\
\end{array}$ & $\begin{array}{c}1 \\
1 \% \\
1\end{array}$ & $\begin{array}{c}9 \\
6 \% \\
18\end{array}$ & $\begin{array}{c}34 \\
24 \% \\
102\end{array}$ & $\begin{array}{c}72 \\
50 \% \\
288\end{array}$ & $\begin{array}{c}28 \\
19 \% \\
140\end{array}$ & $\begin{array}{c}144 \\
100 \% \\
\sum X 549\end{array}$ & 3,812 \\
\hline & $\begin{array}{l}\text { 5. Saya memotret informasi } \\
\text { supporting details } \\
\text { (pengarang, judul, } \\
\text { penerbit, tahun terbit, } \\
\text { cover buku, kata kunci, } \\
\text { daftar isi, daftar pustaka, } \\
\text { singkatan atau simbol) } \\
\text { sebagai cara mencatatnya. }\end{array}$ & $\begin{array}{c}0 \\
0 \% \\
0\end{array}$ & $\begin{array}{c}10 \\
7 \% \\
20\end{array}$ & $\begin{array}{c}17 \\
12 \% \\
51\end{array}$ & $\begin{array}{c}79 \\
55 \% \\
316\end{array}$ & $\begin{array}{c}38 \\
26 \% \\
190\end{array}$ & $\begin{array}{c}144 \\
100 \% \\
\sum X 577\end{array}$ & 4,006 \\
\hline & $\begin{array}{l}\text { 6. Saya memotret informasi } \\
\text { summaries (ringkasan, } \\
\text { abstrak, kesimpulan, } \\
\text { penutup) sebagai cara } \\
\text { mencatatnya. }\end{array}$ & $\begin{array}{c}0 \\
0 \% \\
0\end{array}$ & $\begin{array}{c}11 \\
8 \% \\
22\end{array}$ & $\begin{array}{c}33 \\
23 \% \\
99\end{array}$ & $\begin{array}{c}74 \\
51 \% \\
296\end{array}$ & $\begin{array}{c}26 \\
18 \% \\
130\end{array}$ & $\begin{array}{c}144 \\
100 \% \\
\sum X 547\end{array}$ & 3,789 \\
\hline
\end{tabular}




\section{E. Disrupsi Kamera Digital}

Deskripsi tentang disrupsi kamera digital oleh pemustaka dapat menunjukan data-data berikut ini: Pada indikator ketujuh "Bagi saya mencatat informasi dengan kamera digital menjadi lebih mudah (simpler)" diketahui bahwa 5 (3\%) pemustaka atau responden menjawab tidak setuju, 23 (16\%) responden menjawab kurang setuju, 74 (50\%) responden menjawab setuju, dan 44 (31\%) responden menjawab sangat setuju. Nilai rata-rata 4,131 nilai ini berada pada rentang 3,40 - 4,20 yang berarti pemustaka menilai pernyataan "Bagi saya mencatat informasi dengan kamera digital menjadi lebih mudah (simpler)" dengan tingkat yang tinggi.

Untuk indikator kedelapan yaitu pernyataan "Bagi saya mencatat informasi dengan kamera digital menjadi lebih murah (cheaper)" diketahui bahwa 10 (7\%) pemustaka atau responden menjawab tidak setuju, 19 (13\%) responden menjawab kurang setuju, 83 (58\%) responden menjawab setuju, dan 32 (22\%) responden menjawab sangat setuju. Nilai rata-rata 3,951 nilai ini berada pada rentang 3,40 - 4,20 yang berarti responden menilai pernyataan "Bagi saya mencatat informasi dengan kamera digital menjadi lebih murah (cheaper)" dengan tingkat yang tinggi.

Pada indikator kesembilan yaitu pernyataan "Bagi saya mencatat informasi dengan kamera digital menjadi lebih terjangkau (accessible). Diketahui bahwa 1 (1\%) pemustaka atau responden menjawab sangat tidak setuju, 4 (3\%) responden menjawab tidak setuju, 24 (16\%) responden menjawab kurang setuju, 83 (58\%) responden menjawab setuju, dan 32 (22\%) responden menjawab sangat setuju. Sehingga menghasilkan nilai rata-rata 3,979 nilai ini berada pada rentang 3,40 - 4,20 yang berarti pemustaka menilai pernyataan "Bagi saya mencatat informasi dengan kamera digital menjadi lebih terjangkau (accessible)" dengan tingkat yang tinggi.

Indikator kesepuluh atau terakhir yakni pernyataan "Bagi saya mencatat informasi dengan kamera digital menjadi lebih cepat (faster)" diketahui bahwa 3 (2\%) responden menjawab tidak setuju, 14 (10\%) responden menjawab kurang setuju, 75 (52\%) responden menjawab setuju, 
dan 52 (36\%) responden menjawab sangat setuju. Nilai rata-rata 4,222 nilai ini berada pada rentang 3,40 - 4,20 yang berarti responden menilai pernyataan "Bagi saya mencatat informasi dengan kamera digital menjadi lebih cepat (faster)" dengan tingkat yang tinggi.

Dari keempat indikator tersebut yang memiliki skor tertinggi diperoleh pada pernyataan ketujuh "Bagi saya mencatat informasi dengan kamera digital menjadi lebih cepat (faster)" yang memiliki nilai 4,222. Skor terendah terdapat pada pernyataan kesepuluh "Bagi saya mencatat informasi dengan kamera digital menjadi lebih murah (cheaper)" dengan nilai 3,951. Selengkapnya dapat dilihat pada tabel 4 di bawah ini:

\section{Tabel 4. Disrupsi Kamera Digital}

\begin{tabular}{|c|c|c|c|c|c|c|c|c|}
\hline $\begin{array}{c}\text { Sub } \\
\text { Variabel }\end{array}$ & Indikator & STS(1) & TS(2) & $\mathrm{KS}(3)$ & $S(4)$ & $\operatorname{SS}(5)$ & Jumlah & Mean \\
\hline Disrupsi & 7. Bagi saya mencatat & 0 & 5 & 23 & 74 & 44 & 144 & 4,131 \\
\hline Kamera & informasi dengan & $0 \%$ & $3 \%$ & $16 \%$ & $50 \%$ & $31 \%$ & $100 \%$ & \\
\hline \multirow[t]{10}{*}{ Digital } & $\begin{array}{l}\text { kamera digital men- } \\
\text { jadi lebih mudah } \\
\text { (simpler). }\end{array}$ & 0 & 10 & 69 & 296 & 220 & $\Sigma X 595$ & \\
\hline & 8. Bagi saya mencatat & 0 & 10 & 19 & 83 & 32 & 144 & 3,951 \\
\hline & informasi dengan & $0 \%$ & $7 \%$ & $13 \%$ & $58 \%$ & $22 \%$ & $100 \%$ & \\
\hline & $\begin{array}{l}\text { kamera digital men- } \\
\text { jadi lebih murah } \\
\text { (cheaper). }\end{array}$ & 0 & 20 & 57 & 332 & 160 & $\Sigma X 569$ & \\
\hline & 9. Bagi saya mencatat & 1 & 4 & 24 & 83 & 32 & 144 & 3,979 \\
\hline & informasi dengan & $1 \%$ & $3 \%$ & $16 \%$ & $58 \%$ & $22 \%$ & $100 \%$ & \\
\hline & $\begin{array}{l}\text { kamera digital men- } \\
\text { jadi lebih terjangkau } \\
(\text { accessible })\end{array}$ & 1 & 8 & 72 & 332 & 160 & $\Sigma X 573$ & \\
\hline & 10. Bagi saya mencatat & 0 & 3 & 14 & 75 & 52 & 144 & 4,222 \\
\hline & informasi dengan & $0 \%$ & $2 \%$ & $10 \%$ & $52 \%$ & $36 \%$ & $100 \%$ & \\
\hline & $\begin{array}{l}\text { kamera digital } \\
\text { menjadi lebih cepat } \\
\text { (faster). }\end{array}$ & 0 & 6 & 42 & 300 & 260 & $\Sigma X 608$ & \\
\hline
\end{tabular}




\section{F. Grand Mean}

Mengakhiri pembahasan kajian ini, kiranya perlu untuk melihat keseluruhan dari deskripsi data kuantitatif hasil penelitian. Yaitu dengan penghitungan hasil-hasil tabulasi dalam skema grand mean. Dengan skema grand mean hasil penelitian membantu untuk mengungkapkan kecenderungan yang sedang menggejala dari pemustaka. Sebagaimana tabel grand mean di bawah ini:

\section{Tabel 5. Grand Mean}

\begin{tabular}{|c|c|c|c|c|}
\hline Sub Variabel & Indikator & Mean & $\begin{array}{c}\text { Mean Sub } \\
\text { Variabel }\end{array}$ & $\begin{array}{l}\text { Grand } \\
\text { Mean }\end{array}$ \\
\hline \multirow{3}{*}{$\begin{array}{l}\text { Kepemilikan Ka- } \\
\text { mera Digital }\end{array}$} & $\begin{array}{l}\text { 1. Saya memiliki beberapa macam ka- } \\
\text { mera digital (kamera saku, prosumer, } \\
\text { mirrorless, DSLR, kamera smart- } \\
\text { phone/handphone) }\end{array}$ & 2,993 & \multirow{3}{*}{3,261} & \\
\hline & $\begin{array}{l}\text { 2. Saya memiliki kamera smartphone/ } \\
\text { handphone saja. }\end{array}$ & 3,722 & & \\
\hline & $\begin{array}{l}\text { 3. Saya memiliki kamera digital sejak } \\
\text { usia sekolah. }\end{array}$ & 3,069 & & \\
\hline \multirow{3}{*}{$\begin{array}{l}\text { Pemanfaatan Ka- } \\
\text { mera Digital }\end{array}$} & $\begin{array}{l}\text { 4. Saya memotret informasi main idea } \\
\text { (ide utama, topik bahasan, konsep, } \\
\text { teori, uraian tambahan, ide pen- } \\
\text { dukung) sebagai cara mencatatnya. }\end{array}$ & 3,812 & \multirow{3}{*}{3,872} & \\
\hline & $\begin{array}{l}\text { 5. Saya memotret informasi supporting } \\
\text { details (pengarang, judul, penerbit, } \\
\text { tahun terbit, cover buku, kata } \\
\text { kunci, daftar isi, daftar pustaka, } \\
\text { singkatan atau simbol) sebagai cara } \\
\text { mencatatnya. }\end{array}$ & 4,006 & & 3,734 \\
\hline & $\begin{array}{l}\text { 6. Saya memotret informasi summaries } \\
\text { (ringkasan, abstrak, kesimpulan, } \\
\text { penutup) sebagai cara mencatatnya. }\end{array}$ & 3,798 & & \\
\hline \multirow{2}{*}{$\begin{array}{l}\text { Disrupsi Kamera } \\
\text { Digital }\end{array}$} & $\begin{array}{l}\text { 7. Bagi saya mencatat informasi dengan } \\
\text { kamera digital menjadi lebih mudah } \\
\text { (simpler). }\end{array}$ & 4,131 & \multirow[t]{2}{*}{4,071} & \\
\hline & $\begin{array}{l}\text { 8. Bagi saya mencatat informasi dengan } \\
\text { kamera digital menjadi lebih murah } \\
\text { (cheaper). }\end{array}$ & 3,951 & & \\
\hline
\end{tabular}




\begin{tabular}{|c|c|c|c|c|}
\hline Sub Variabel & Indikator & Mean & $\begin{array}{c}\text { Mean Sub } \\
\text { Variabel }\end{array}$ & $\begin{array}{l}\text { Grand } \\
\text { Mean }\end{array}$ \\
\hline & $\begin{array}{l}\text { 9. Bagi saya mencatat informasi dengan } \\
\text { kamera digital menjadi lebih terjang- } \\
\text { kau (accessible) }\end{array}$ & 3,979 & & \\
\hline & $\begin{array}{l}\text { 10. Bagi saya mencatat informasi dengan ka- } \\
\text { mera digital menjadi lebih cepat (faster). }\end{array}$ & 4,222 & & \\
\hline
\end{tabular}

Tabel 5 menyajikan seluruh nilai dari kesepuluh indikator yang menjadi pernyataan dalam kuesioner untuk pemustaka. Dari data yang tersaji dalam tabel pada kolom mean menginformasikan rerata nilai jawaban pemustaka dari sepuluh indikator penelitian. Kemudian hasil perhitungan grand mean diperuntukan bagi nilai pengukuran variabel utama atau variabel pemanfaatan kamera digital oleh pemustaka yang menunjukan nilai sebesar 3,734. Nilai ini adalah berada pada rentang skala 3,40 - 4,20 yang berarti memiliki tingkat yang tinggi.

Dari kesepuluh butir indikator pemanfaatan kamera digital oleh pemustaka, diketahui bahwa skor tertinggi terdapat pada indikator kesepuluh yaitu "Bagi saya mencatat informasi dengan kamera digital menjadi lebih cepat (faster)" dengan nilai 4,222. Nilai ini berada pada rentang 4,20 - 5,00 sehingga berarti memiliki tingkat yang sangat tinggi. Disusul oleh indikator ketujuh yaitu: "Bagi saya mencatat informasi dengan kamera digital menjadi lebih mudah (simpler)" dengan skor nilai 4,131. Kemudian indikator kelima "Saya memotret informasi supporting details (pengarang, judul, penerbit, tahun terbit, cover buku, kata kunci, daftar isi, daftar pustaka, singkatan atau simbol) sebagai cara mencatatnya" dengan nilai 4.006. Kedua indikator tersebut (7\&5) berada pada rentang yang sama yaitu pada skala 3,40 - 4,20 yang berarti memiliki tingkat yang tinggi.

Indikator yang mendapatkan skor di bawah rata-rata atau di bawah grand mean 3,734 yaitu: secara berurutan dari yang terendah adalah indikator pertama, ketiga dan kedua. Indikator pertama "Saya memiliki beberapa macam kamera digital (kamera saku, prosumer, mirrorless, DSLR, kamera smartphone/ handphone) dengan 2,993 skor nilai. Indikator ketiga "Saya memiliki kamera 
digital sejak usia sekolah" dengan 3,069 skor nilai. Indikator kedua Saya memiliki kamera smartphone / handphone saja." dengan 3,722 skor nilai.

Secara umum pemanfaatan kamera digital oleh pemustaka menunjukan nilai yang cukup tinggi, artinya pemustaka sudah begitu dekat dengan aktivitas penggunaan kamera digital yang dalam hal ini pemustaka umumnya memiliki kamera smartphone. Pemustaka cenderung galau untuk mengungkapkan sejak kapan kepemilikan kamera digital. Hal ini juga dikuatkan dengan data bahwa semua indikator kepemilikan kamera digital berada di bawah nilai grand mean. Namun yang pasti adalah terdapat fenomena disrupsi dengan alasan kuat bahwa perubahan itu dirasakan menjadi lebih cepat (faster) kemudian alasan lain adalah lebih mudah (simpler). Apa yang menjadi objek bidikan kamera yaitu yang paling menonjol adalah "Saya memotret informasi supporting details (pengarang, judul, penerbit, tahun terbit, cover buku, kata kunci, daftar isi, daftar pustaka, singkatan atau simbol) sebagai cara mencatatnya”. Kita sepertinya mendapatkan kabar baik tentang data ini yaitu bahwa pemustaka cukup berhati-hati dan rasional untuk memanfaatkan kamera digital di lingkup perpustakaan. Terbukti hanya mengambil catatan kecil tentang informasi supporting details. Ini tentunya berfungsi untuk membantu sebagai indeks ingatan ketika hendak melakukan temu-kembali informasi buku tersebut, atau untuk membantu membuat daftar pustaka dalam karya tulis mereka.

\section{KESIMPULAN}

Melihat dari data penelitian tersebut diatas terungkap bahwa: Pertama, kepemilikan kamera digital dari pemustaka pada umumnya mereka memiliki kamera smartphone/handphone saja. Pemustaka yang memiliki beberapa macam kamera digital hanya sebagian kecil saja. Upaya untuk mengungkapkan sejak kapan mereka memiliki kamera digital umumnya merasa enggan untuk menyampaikannya secara langsung. Kedua, mengenai pemanfaatan atau penggunaan kamera digital oleh pemustaka di perpustakaan paling menonjol adalah untuk memotret informasi supporting details (pengarang, judul, penerbit, tahun terbit, cover buku, kata kunci, daftar 
isi, daftar pustaka, singkatan atau simbol) sebagai cara mencatatnya. Daripada untuk memotret informasi main idea dan atau memotret informasi summarie; Hal ini dapat diartikan bahwa pemustaka umumnya hanya membuat catatan kecil atau sederhana untuk membantu mengingat detail dari judul buku, pengarang, tahun terbit dan lain-lainnya. Untuk kemudian menyimpannya dalam catatan digital mereka, supaya pada saat mereka membutuhkan dapat ditelusuri dan ditemukan kembali.

Ketiga, terkait dengan disrupsi kamera digital terhadap pencatatan informasi pemustaka di perpustakaan sebagai alasan utama atau yang paling menonjol adalah bahwa bagi mereka mencatat informasi dengan kamera digital menjadi lebih cepat (faster). Disusul oleh alasan mencatat informasi dengan kamera digital menjadi lebih mudah (simpler). Sementara alasan lebih terjangkau (accessible) dan lebih murah (cheaper) adalah faktor disrupsi yang menyertai kemudian setelah dua alasan tersebut. Ini memiliki makna atau bisa ditafsirkan bahwa para pemustaka dalam pemanfaatan kamera digital cukup selektif memiliki kecermatan yang patut dihargai. Pemustaka tidak asal murah saja dalam membuat catatan namun lebih mempertimbangkan kecepatan dan kemudahan hal ini dapat dimaklumi karena fenomena sekarang kamera digital selalu dalam genggaman mereka. Kemanapun mereka pergi selalu membawa smartphone yang sudah tertanam dengan kamera digital.

Ketiga hal tersebut membawa implikasi bahwa terdapat indikasi perubahan dan pergeseran dalam dunia teknologi khusus berkaitan dengan pemanfaatan kamera digital oleh pemustaka di perpustakaan. Hal ini perlu mendapatkan perhatian dan antisipasi positif dari sisi manajemen layanan perpustakaan. Perpustakaan dengan pemustaka wajib saling mendukung untuk terciptanya ekosistem perpustakaan yang berkembang dan berkesinambungan secara nyaman; perpustakaan memiliki regulasi sementara pemustaka memiliki aspirasi. Pemustaka memiliki kebebasan dalam menyalin informasi melalui memotret dengan kamera digital yang dimiliki. Aturan atau tata tertib tentang pelarangan menggunakan kamera dalam perpustakaan tentunya bisa diselaraskan dengan perkembangan teknologi saat ini. 


\section{DAFTAR PUSTAKA}

"Kamera Digital" dalam Wikipedia diakses melalui https://id.wikipedia.org/ wiki/Kamera_digital pada tanggal 22 Maret 2019.

Aliya, Nadira. 2019. "Sejarah Kamera: Perkembangan Kamera Fotografi dari Masa ke Masa" dalam Folder Tekno diakses melalui https://www. foldertekno.com/sejarah-kamera/ pada tanggal 8 April 2019.

Arikunto, Suharsimi. 1985. Prosedur Penelitian Suatu Pendekatan Praktik. Jakarta: Bina Aksara.

Azwar, Saifuddin. 2012. Reliabilitas dan Validitas. Yogyakarta: Pustaka Pelajar. Balai Pustaka. 1999. Kamus Besar Bahasa Indonesia. Edisi Kedua. Jakarta: Balai Pustaka.

Kasali, Rhenald. 2017. Disruption: Tak Ada yang Tak Bisa Diubah Sebelum Dihadapi, Motivasi Saja Tidak Cukup. Jakarta: Gramedia Pustaka Utama.

Mahendra, Yannes Irwan. 2010. Dari Hobi Jadi Profesional. Yogyakarta: Andi. McKee, Bob. 1989. Planning Library Service. London: Clive Bingley.

Republik Indonesia (s.a.). Undang-Undang Republik Indonesia Nomor 43 Tahun 2007 Tentang Perpustakaan. Yogyakarta: Graha Ilmu.

Sadono, Sri. 2015. Bedah Kamera. Jakarta: Elex Media Komputindo.

Setiyono, Joko. 2017. “Ayo Sowan Simbah” dalam Kolom Gagasan Solopos pada tanggal 14 September 2017.

Setiyono, Joko. 2019. Kamera Digital di Tangan Pemustaka. Surakarta: ISI Press.

Sulistyo-Basuki. 1999. Pengantar Ilmu Perpustakaan. Jakarta: Gramedia Pustaka Utama.

Suwarno, Wiji. 2009. Psikologi Perpustakaan. Jakarta: Sagung Seto.

Suwarno, Wiji. 2010. Pengetahuan Dasar Kepustakaan. Bogor: Penerbit Ghalia Indonesia.

Toffler, Alvin. 1980. Gelombang Ketiga (The Third Wave). Jakarta: Pantja Simpati. 